\title{
Efektivitas Perasan Daun Kemangi (Ocimum basilicum) dibanding Larutan Pembersih Gigi Tiruan Effervescent sebagai Pembersih Gigi Tiruan Resin Akrilik terhadap Pertumbuhan Candida albicans
}

\author{
(Effectiveness of Basil (Ocimum basilicum) Leaves Squeeze \\ Compared to Effervescent Denture Cleaning Solution as \\ Acrylic Resin Denture Cleaners on the Growth of \\ Candida albicans
}

\author{
Sherlika Puspita Sari ${ }^{1}$, Achmad Gunadi ${ }^{2}$, Dewi Kristiana ${ }^{2}$ \\ ${ }^{1}$ Fakultas Kedokteran Gigi, Universitas Jember \\ ${ }^{2}$ Bagian Prostodonsia Fakultas Kedokteran Gigi, Universitas Jember \\ JIn. Kalimantan No.37, Kampus Tegalboto, Jember 68121 \\ e-mail:sherlikah@gmail.com
}

\begin{abstract}
The heat cured acrylic resin is common used as denture base material, but its microporosity can affect the cleanliness of the denture base lead to accumulation of plaque and food waste, and further increase the number of Candida albicans and cause denture stomatitis. There are 2 type of cleaning agents; natural cleaning agents, such as basil and chemical cleaning agents, for example effervescent artificial cleaning tablets. This study compared the effectiveness of basil leaves squeeze and effervescent denture cleaning solutions in soaking heat cured acrylic resin plates on the growth of C. albicans. There were 24

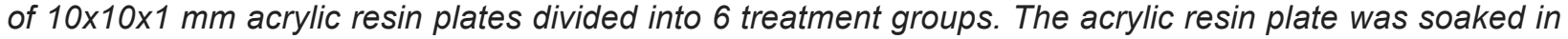
the basil leaves squeeze and effervescent denture cleaning solutions. Measurement of C. albicans absorbance used a spectrophotometer, then calculated the total of C. albicans using the formula. Data was analyzed using the One Way ANOVA test. The analysis showed that there are significant differences on the growth inhibition of $C$. albicans between treatment groups $(p<0.005)$. The effervescent denture cleansing solution has a better antifungal effectiveness than the basil leaves
\end{abstract}

Keywords : acrylic resin, basil leaves, effervescent denture cleaning solution, Candida albicans

\begin{abstract}
Abstrak
Resin akrilik heat cured merupakan bahan basis gigi tiruan yang paling banyak digunakan, tetapi mikroporositasnya dapat mempengaruhi kebersihan basis gigi tiruan yang dapat mengakibatkan penumpukan plak dan sisa makanan sehingga meningkatkan jumlah Candida albicans dan menjadi penyebab denture stomatitis. Ada dua jenis bahan pembersih, yaitu bahan pembersih alami, misalnya kemangi dan bahan pembersih kimia, misalnya tablet pembersih gigi-tiruan effervescent. Penelitian ini bertujuan untuk mengetahui perbandingan efektivitas perasan daun kemangi dan larutan pembersih gigitiruan effervescent pada perendaman plat resin akrilik heat cured, terhadap pertumbuhan jamur $C$. albicans. Sampel yang digunakan sebanyak 24 lempeng resin akrilik berukuran 10x10x1 mm dibagi ke dalam 6 kelompok perlakuan. Lempeng resin akrilik direndam dalam perasan daun kemangi dan larutan pembersih gigi-tiruan effervescent. Pengukuran absorbansi C.albicans menggunakan spektrofotometer, kemudian dihitung jumlah total $C$. albicans menggunakan rumus. Data dianalisis menggunakan uji One Way ANOVA. Hasil analisis menunjukkan terdapat perbedaan yang bermakna pada daya hambat pertumbuhan $C$. albicans yang terjadi antar kelompok perlakuan $(p<0,005)$. Larutan tablet pembersih gigitiruan effervescent memiliki efektivitas antifungi yang lebih baik dibandingkan dengan perasan daun kemangi.
\end{abstract}

Kata kunci: resin akrilik, daun kemangi, pembersih gigi tiruan effervescent, Candida albicans 


\section{Pendahuluan}

Gigi tiruan lepasan merupakan protesa yang dapat dikeluarkan dari mulut pasien untuk dibersihkan, diperiksa, dan diperbaiki. Gigi tiruan lepasan melibatkan dua jenis protesa yaitu gigi tiruan sebagian dan gigi tiruan lengkap [1] Pada pasien lanjut usia, banyak dari mereka akan memerlukan gigi tiruan lengkap atau gigi tiruan sebagian untuk menggantikan gigi yang hilang karena akan berpengaruh positif terhadap kualitas hidup mereka. Resin akrilik yang teraktivasi panas merupakan jenis akrilik yang banyak digunakan sebagai bahan basis gigi tiruan [2]. Salah satu keuntungan resin akrilik teraktivasi panas yaitu relatif mudah dalam pengerjaannya. Kelemahan dari resin akrilik ini yaitu adanya mikroporositas. Adanya mikroporositas ini dapat mempengaruhi sifat fisik, estetika, dan kebersihan basis gigi tiruan resin akrilik [3]. Kebersihan yang kurang diperhatikan akan mengakibatkan penumpukan plak dan sisa makanan, sehingga dapat meningkatkan jumlah sel Candida albicans dan menjadi penyebab denture stomatitis [4]

Menurut Lee et al (2011) bahwa menyikat, merendam dalam larutan tablet pembersih gigitiruan, atau kombinasi keduanya dapat secara signifikan mengurangi jamur $C$. albicans pada geligi tiruan [5]. Penelitian yang dilakukan Suni et al (2017) menunjukkan bahwa sodium bikarbonat dan asam sitrat pada pembersih gigitiruan effervescent menghasilkan pembersihan kimia pada gigi-tiruan yang dapat menghilangkan deposit. Selain menggunakan bahan kimia, dapat pula menggunakan bahanbahan alam sebagai alternatif pembersih gigi tiruan [6]. Salah satu bahan alam yang dapat dimanfaatkan kandungannya sebagai tanaman obat adalah kemangi [7]. Pada penelitian Hidayat et al (2007) daun kemangi mengandung senyawa antimikroba yaitu fenol, tanin, flavonoid, saponin dan alkaloid yang dapat menghambat pertumbuhan jamur C. Albicans [8]. Tujuan dari penelitian ini adalah mengetahui perbandingan efektivitas perasan daun kemangi dengan konsentrasi 25\%, 50\%, 75\%, 100\% selama 6 jam dan larutan pembersih gigi-tiruan effervescent selama 15 menit pada perendaman plat resin akrilik heat cured, terhadap pertumbuhan jamur $C$. albicans.

\section{Metode Penelitian}

Penelitian ini merupakan jenis penelitian experimental laboratory dengan rancangan penelitian Post test-only control group design. Penelitian ini dilaksanakan di Laboratorium Bahan dan Teknologi FKG Universitas Negeri Jember dan Laboratorium mikrobiologi FKG Universitas Negeri Jember pada bulan September-Oktober 2018. Besar sampel adalah 24 buah berbentuk persegi dengan ukuran $10 \times 10 \times 1 \mathrm{~mm}$ untuk 6 kelompok yang masingmasing berjumlah 4 buah.

Pembuatan air perasan daun kemangi dilakukan dengan cara memilih daun kemangi yang segar dengan berat 50 gram. Daun kemangi dibersihkan dengan air mengalir lalu dimasukkan ke dalam blender hingga halus. Air perasan kemudian disaring menggunakan kain flannel yang telah disterilkan dan sarinya ditampung. Air perasan yang diperoleh mempunyai konsentrasi $100 \%$, dan volume air perasan yang diperoleh $10 \mathrm{ml}$ lalu disaring dengan millipore filter steril 0,22 $\mu \mathrm{m}$. Perasan daun kemangi yang digunakan dibagi menjadi 4 konsentrasi, yaitu konsentrasi $25 \%, 50 \%, 75 \%$, dan $100 \%$.

Pembuatan larutan pembersih gigi tiruan effervescent dengan melakukan pengenceran tablet pembersih gigi tiruan effervescent sesuai dengan anjuran pada kemasan produk, prosedur pembuatan tablet pembersih gigi tiruan effervescent yaitu $100 \mathrm{ml}$ air hangat dalam gelas masukkan tablet pembersih gigi-tiruan effervescent ke dalam air hangat tersebut sampai tablet terlihat habis [9].

Plat resin akrilik ukuran $10 \times 10 \times 1 \mathrm{~mm}$ direndam menggunakan aquades steril selama 48 jam untuk mengurangi sisa monomer, kemudian disterilisasi dengan menggunakan autoclave $121^{\circ} \mathrm{C}$ selama 15 menit. Plat resin akrilik direndam dalam saliva buatan selama 1 jam, kemudian dibilas menggunakan larutan phosphat buffer saline (PBS) masing-masing dua kali. Plat resin akrilik heat cured dimasukkan dalam tabung reaksi yang masingmasing berisi suspense jamur candida albicans. Plat resin akrilik heat cured direndam dalam tabung reaksi berisi air perasan daun kemangi dengan 4 macam konsentrasi, yaitu 100\%, 75\%, $50 \%$ dan $25 \%$ selama 6 jam, larutan pembersih gigi tiruan effervescent selama 15 menit dan 
aquades steril. Setelah itu plat resin akrilik dibilas menggunakan PBS sebanyak 2 kali kemudian dimasukkan ke dalam $4 \mathrm{ml}$ Saboraud broth, kemudian dilakukan vibrasi dengan vortex pada semua tabung reaksi selama 30 detik untuk melepaskan jamur C. albicans yang melekat pada lempeng. kemudian dilakukan penghitungan menggunakan spektrofotometer dengan standard Mc Farland no 1 dengan panjang gelombang $560 \mathrm{~nm}$. Kemudian nilai absorbansi tersebut dilakukan penghitungan jumlah sel dengan menggunakan rumus Stainer.

Data hasil uji kekasaran permukaan kemudian dianalisis dengan uji normalitas dengan uji Kolmogorov-Smirnov dan uji homogenitas dengan uji Levene. Selanjutnya dilakukan uji parametrik One-Way Anova dan dilanjutkan uji Least Significance Difference untuk mengetahui konsentrasi bahan perendaman yang paling efektif.

\section{Hasil}

Hasil penelitian mengenai potensi berbagai konsentrasi perasan daun kemangi (Ocimum basilicum) sebagai alternatif pembersih gigi tiruan resin akrilik terhadap pertumbuhan jamur Candida albicans diperoleh nilai absorbansi kekeruhan C.albicans beserta medianya pada masing-masing sampel penelitian disajikan pada Tabel 1.

Tabel 1.Hasil pengukuran absorbansi kekeruhan C.albicans berserta medianya dengan menggunakan spektrofotometer

\begin{tabular}{|c|c|c|c|c|c|c|}
\hline \multirow{3}{*}{ Sampel } & \multicolumn{6}{|c|}{ Perendaman } \\
\hline & Perasan & Perasan & Perasan & Perasan & Larutan & \\
\hline & Daun & Daun & Daun & Daun & Pembersih & Aquades \\
\hline & Kemangi & Kemangi & Kemangi & Kemangi & Gigi-Tiruan & Steril \\
\hline & $25 \%$ & $50 \%$ & $75 \%$ & $100 \%$ & Effervescent & \\
\hline 1 & 0,150 & 0,135 & 0,125 & 0,115 & 0,100 & $0,175^{*}$ \\
\hline 2 & 0,150 & 0,140 & 0,130 & 0,120 & 0,105 & 0,180 \\
\hline 3 & 0,155 & 0,140 & 0,130 & 0,120 & 0,110 & 0,185 \\
\hline 4 & 0,155 & 0,140 & 0,130 & 0,115 & 0,100 & 0,180 \\
\hline Mean & 0,152 & 0,138 & 0,128 & 0,117 & 0,103 & 0,180 \\
\hline
\end{tabular}

Dari hasil pembacaan pada Tabel 1 kemudian dilakukan perhitungan jumlah sel $C$. albicans pada plat akrilik dengan rumus berikut [10]:

$\mathrm{N}=\frac{\text { (nilai absorban media }+ \text { C. albicans) - (nilai absorbansi media) }}{\text { Nilai absorban larutan standar Mc. Farland } 1} \times \mathrm{X}$

Keterangan :

$\mathrm{X}=$ konsentrasi jamur dari larutan standar Mc. Farland no. $1=3.10^{8} \mathrm{CFU} / \mathrm{ml}$
$\mathrm{N}$ =hasil perhitungan nilai absorbansi $C$. albicans pada lempeng resin akrilik yang telah dikonversikan ke dalam rumus setelah direndam dalam bahan perendaman (CFU/ml)

Nilai absorbansi media Saboraud broth tanpa jamur $=0,01$

Nilai absorbansi larutan standar Mc Farland no. $1=0,15$

Panjang gelombang pada saat pengukuran yang digunakan $=560 \mathrm{~nm}$

Hasil perhitungan jumlah sel $C$. albicans pada lempeng resin akrilik setelah dikonversikan dalam rumus tersebut dapat dilihat pada Tabel 2.

Tabel 2. Hasil perhitungan nilai absorbansi $C$. albicans pada lempeng resin akrilik yang telah dikonversikan ke dalam rumus setelah direndam dalam bahan perendaman (CFU/ml)

\begin{tabular}{|c|c|c|c|c|c|c|}
\hline \multirow{5}{*}{ Sampel } & \multicolumn{6}{|c|}{ Perendaman } \\
\hline & Perasan & Perasan & Perasan & Perasan & Larutan & \\
\hline & Daun & Daun & Daun & Daun & Pembersih & Aquades \\
\hline & Kemangi & Kemangi & Kemangi & Kemangi & Gigi-Tiruan & Steril \\
\hline & $25 \%$ & $50 \%$ & $75 \%$ & $100 \%$ & Effervescent & \\
\hline 1 & 2.8 & 2.5 & 2.3 & 2.1 & 1,8 & $3,3^{*}$ \\
\hline 2 & 2.8 & 2,6 & 2,4 & 2,2 & 1,9 & 3,4 \\
\hline 3 & 2.9 & 2.6 & 2,4 & 2,2 & 2,0 & 3,5 \\
\hline 4 & 2.9 & 2.6 & 2,4 & 2,1 & 1,8 & 3,4 \\
\hline Mean & 2,85 & 2,57 & 2,37 & 2,15 & 1,87 & 3,40 \\
\hline
\end{tabular}

jumlah sel rata-rata $C$. albicans pada masing-masing perlakuan

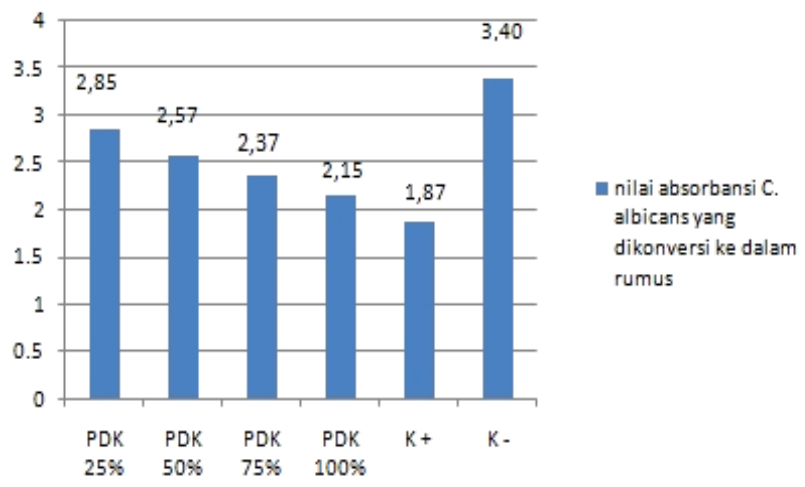

dalam bahan perendaman

Keterangan :

PDK 25\% : Perasan Daun Kemangi 25\%

PDK 50\% : Perasan Daun Kemangi 50\%

PDK 75\% : Perasan Daun Kemangi 75\%

PDK 100\% : Perasan Dauk Kemangi 100\%

$\mathrm{K}+\quad$ : Kontrol Positif ( Larutan effervescent)

K- $\quad$ : Kontrol Negatif (Aquades steril) 
Hasil pengukuran pada penelitian ini dianalisis secara statistik untuk mengetahui normalitas, homogenitas, dan perbedaan antar kelompok perlakuan. Hasil uji normalitas menggunakan uji Kolmogorov-Smirnov menunjukkan nilai signifikansi atau probability (p) lebih besar dari 0,05 ( $p>0,05)$. Hal ini menunjukkan bahwa data dari masing-masing kelompok berdistribusi normal. Hasil uji homogenitas menggunakan uji Levene diperoleh hasil nilai signifikansi sebesar 0,617 . Hasil uji tersebut menunjukan bahwa data pada penelitian ini homogen karena diperoleh nilai signifikansi $p>0,05$. Berdasarkan hasil uji normalitas dan homogenitas diperoleh hasil bahwa data terdistribusi normal dan homogeny sehingga dilanjutkan uji One-Way Anova,

Analisa dilanjutkan dengan uji statistik parametrik dengan menggunakan uji One Way ANOVA untuk mengetahui adanya perbedaan antar kelompok perlakuan. Hasil analisis menunjukkan nilai signifikansi 0,000 dimana nilai tersebut kurang dari $0,05(p<0,05)$, sehingga dapat disimpulkan bahwa diantara kelompok perlakuan terdapat perbedaan yang bermakna. Selanjutnya dilakukan uji Least Signification Different ( $L S D$ ) untuk mengetahui perbedaan pada setiap kelompok perlakuan. Hasil analisis diperoleh bahwa terdapat perbedaan signifikansi pada masing-masing kelompok dengan nilai signifikansi kurang dari 0,05.

\section{Pembahasan}

Pada penelitian ini lempeng resin akrilik heat cured digunakan sebagai sampel basis gigi-tiruan. Lempeng resin akrilik pada penelitian ini tidak dilakukan pemulasan pada kedua permukaannya sesuai dengan kondisi basis gigitiruan yang menghadap rongga mulut. Lempeng akrilik tersebut dikontaminasi jamur C. albicans, selanjutnya dilakukan perendaman dengan perasan daun kemangi $25 \%, 50 \%, 75 \%, 100 \%$, larutan pembersih gigi-tiruan effervescent sebagai kontrol positif, dan aquades steril sebagai kontrol negatif. Perbedaan konsentrasi perasan daun kemangi ini bertujuan untuk mengetahui konsentrasi bahan perendaman yang efektif sebagai pembersih gigi-tiruan resin akrilik heat cured.

Berdasarkan penelitian yang telah dilakukan, tabel 1 menunjukkan nilai absorbansi kekeruhan $C$. Albicans beserta medianya dengan menggunakan spektrofotometer. Nilai absorbansi dapat diketahui dengan cara mengukur media Saboraud's Dextrose Broth (SDB) yang telah terkontaminasi oleh $C$. albicans. Berdasarkan tabel 1 dapat dilihat bahwa aquades steril memiliki nilai absorbansi optical density (OD) C. albicans tertinggi sebesar 0,180. Pada perasan daun kemangi $25 \%$ terdapat penurunan nilai absorbansi OD $C$. albicans sebesar 0,152 , nilai absorbansi OD pada perasan daun kemangi $50 \%$ sebesar 0,138 , nilai absorbansi OD pada perasan daun kemangi $75 \%$ sebesar 0,128 dan nilai absorbansi OD pada perasan daun kemangi $100 \%$ sebesar 0,117 . Sedangkan, larutan tablet pembersih gigi-tiruan effervescent memiliki nilai absorbansi OD terendah yaitu sebesar 0,103, sehingga dapat diambil kesimpulan bahwa nilai absorbansi OD $C$. albicans semakin menurun seiring dengan peningkatan konsentrasi perasan daun kemangi.

Hasil rata-rata $C$. albicans setelah nilai absorbansi kekeruhan $C$. albicans dikonversikan ke dalam rumus pada tabel 2. menunjukkan perbedaan antara masing-masing perlakuan. Hal ini bisa dilihat pada tabel 2, dimana hasil rata-rata jumlah sel $C$. albicans yang terlepas pada bahan perendaman perasan daun kemangi $25 \%$ sebesar $2,85 \times 10^{8} \mathrm{CFU} / \mathrm{ml}$, pada perasan daun kemangi $50 \%$ sebesar 2,57 $\times 10^{8}$ $\mathrm{CFU} / \mathrm{ml}$, pada perasan daun kemangi $75 \%$ sebesar 2,37 x $10^{8} \mathrm{CFU} / \mathrm{ml}$, pada perasan daun kemangi $100 \%$ sebesar $2,15 \times 10^{8} \mathrm{CFU} / \mathrm{ml}$, pada larutan tablet pembersih gigi-tiruan effervescent sebesar $1,87 \times 10^{8} \mathrm{CFU} / \mathrm{ml}$, dan pada aquades steril sebesar $3,40 \times 10^{8} \mathrm{CFU} / \mathrm{ml}$.

Dari hasil penelitian ini, dapat dilihat bahwa perasan daun kemangi mampu menghambat pertumbuhan jamur $C$. albicans pada resin akrilik heat cured dan terlihat adanya penurunan jumlah sel $C$. albicans pada lempeng resin akrilik yang direndam pada berbagai konsentasi perasan daun kemangi dibandingkan dengan perendaman menggunakan aqudes steril sebagai kontrol. Penurunan jumlah sel $C$. albicans terbesar yang direndam pada perasan daun kemangi nampak pada perendaman dengan konsentrasi $100 \%$ atau dengan kata lain, perasan daun kemangi $100 \%$ memiliki efektivitas yang lebih baik dibanding perasan daun kemangi $25 \%, 50 \%, 75 \%$, dan aquades steril.

Peningkatan konsentrasi perasan daun kemangi mempengaruhi jumlah sel $C$. albicans pada lempeng resin akrilik. Semakin tinggi konsentrasi bahan, maka akan semakin tinggi pula kandungan bahan aktif yang ada di dalamnya. Perasan daun kemangi mampu 
menghambat pertumbuhan C. albicans karena memiliki kandungan senyawa aktif yaitu alkaloid, fenol, tanin, flavonoid dan saponin [8].

Menurut penelitian Ornay et al (2017) senyawa aktif alkaloid, fenol, tanin, flavonoid dan saponin dalam kemangi dapat menghambat dan membunuh C. Albicans [11]. Senyawa antijamur yang terkandung didalam daun kemangi tersebut didukung oleh penelitian Soleman \& Setiawan (2017) yang menyatakan bahwa senyawa aktif alkaloid, tanin, flavonoid dan saponin yang terkandung didalam kulit batang jambu mete memiliki aktivitas antijamur terhadap C. Albicans [12]. Selain itu menurut penelitian Vifta et al (2018) menyatakan bahwa senyawa aktif alkaloid, tanin, flavonoid dan saponin didalam biji timun suri dapat menghambat pertumbuhan jamur $C$. Albicans [13].

Mustikasari dan Ariyani (2010) menyatakan bahwa senyawa alkaloid memiliki aktivitas sebagai antimikroba dengan merusak dinding sel mikroba [14]. Senyawa alkaloid bersifat basa $\mathrm{pH}>7$. Sifat basa ini kemungkinan akan menekan pertumbuhan jamur $C$. albicans karena jamur tersebut tumbuh pada $\mathrm{pH} 4,5-6,5$ [15].

Pada penelitian Pulungan (2017) sebagai antifungi senyawa fenol dapat berdifusi pada membran sel jamur dan mengganggu jalur metabolik seperti sintesis ergosterol, glukan, kitin, protein, dan glukosamin di jamur. Senyawa fenol akan berikatan dengan ergosterol yang merupakan penyusun membran sel jamur sehingga menyebabkan terbentuknya suatu pori pada membran sel. Terbentuknya pori tersebut menyebabkan komponen sel jamur seperti asam amino, asam karboksilat, fosfat anorganik dan ester fosfat keluar dari sel hingga menyebabkan kematian sel jamur [16].

Penelitian yang dilakukan Ningsih et al (2017) tanin berperan sebagai senyawa antijamur terhadap C. Albicans [17]. Menurut Djunaedy (2008) senyawa antijamur memiliki mekanisme kerja dengan cara menetralisasi enzim yang terkait dalam invasi jamur, merusak membran sel jamur, menghambat sistem enzim jamur sehingga mengganggu terbentuknya ujung hifa dan mempengaruhi sintesis asam nukleat dan protein [18].

Flavonoid adalah senyawa golongan fenol yang dapat bekerja sebagai antijamur dengan cara menghambat sintesis nukleat jamur. Flavonoid juga dapat mencegah pertumbuhan jamur dengan cara mengganggu kestabilan membran sel dan metabolisme sel jamur sehingga dapat mengakibatkan gangguan pertukaran cairan di dalam sel [19]. Hasil penelitian Soleman \& Setiawan (2017) tentang flavonoid yang terkandung pada ekstrak metanol kulit batang jambu mete juga terbukti dapat menghambat pertumbuhan $C$. Albicans [12].

Menurut penelitian Yuliana et al (2015) saponin dapat menghambat pertumbuhan jamur C. albicans. Saponin mempunyai aktivitas sebagai antijamur dengan mekanisme kerjanya yaitu dengan cara merusak membran sel, sehingga menyebabkan kebocoran sel berupa keluarnya berbagai komponen penting dari dalam sel jamur yaitu protein, asam nukleat dan nukleotida yang akhirnya memacu kematian sel [20]. Selain itu menurut Pulungan (2017) saponin memiliki kemampuan sebagai antijamur dengan mekanisme menurunkan tegangan permukaan membran sterol dari dinding $C$. albicans, sehingga permeabilitasnya meningkat. Permeabilitas yang meningkat mengakibatkan cairan intraseluler yang lebih pekat tertarik keluar sel sehingga sel $C$. albicans mengalami kematian karena sel membengkak dan pecah [16].

Sedangkan perendaman dengan aquades steril memiliki efektivitas paling rendah dalam menghambat pertumbuhan jamur $C$. albicans. Perendaman lempeng resin akrilik dengan aquades steril didapatkan jumlah sel $C$. albicans terbanyak. Hal ini disebabkan tidak adanya kandungan antijamur dalam aquades steril.

Pada penelitian ini perasan daun kemangi dengan konsentrasi $100 \%$ dapat menghambat pertumbuhan jamur $C$. albicans dengan jumlah penurunan terbesar dibandingkan dengan konsentrasi lain, namun belum efektif menghambat pertumbuhan jamur $C$. albicans dibandingkan dengan larutan tablet pembersih gigi-tiruan effervescent sebagai kontrol positif. Menurut penelitian yang dilakukan Faot et al (2014) efektivitas tablet pembersih gigi-tiruan dalam menghambat pertumbuhan jamur $C$. albicans tidak terlepas dari adanya kandungan bahan yang terkandung dalam tablet pembersih gigi-tiruan itu seperti asam sitrat. Asam sitrat berperan sebagai agen chemotherapeutic yang dapat menghancurkan biofilm melalui mekanisme ion kalsium. Mekanisme ini menyebabkan asam sitrat merusak calcium bridges dan merusak matrix biofilm sehingga terjadi aktivitas antibiofilm [21]. Suni et al (2017) juga menyatakan bahwa sodium bikarbonat dan asam sitrat pada pembersih gigi-tiruan effervescent menghasilkan pembersihan kimia pada gigi-tiruan yang dapat menghilangkan 
deposit [6]. Selain itu menurut penelitian Pambudi et al (2017) pembersih gigi-tiruan dalam bentuk tablet saat dilarutkan dalam air hangat, sodium perborat akan terurai dan membentuk alkalin peroksida kemudian senyawa ini melepaskan oksigen dan terjadi aksi pembersihan terhadap mikroba dan stain pada basis gigi-tiruan [9].

Pada penelitian ini menunjukkan bahwa merendam gigi-tiruan dalam larutan tablet pembersih gigi-tiruan effervescent selama 15 menit sesuai anjuran produk, lebih efektif menghambat pertumbuhan jamur $C$. albicans dibanding perendaman dalam perasan daun kemangi dengan konsentrasi $25 \%, 50 \%, 75 \%$, $100 \%$ dan aquades steril selama 6 jam sesuai dengan waktu rata-rata pengguna gigi tiruan merendam gigi tiruan pada malam hari saat beristirahat [6]. Akan tetapi, efek perendaman yang terlalu lama didalam larutan tablet pembersih gigi-tiruan dapat menyebabkan perubahan warna resin akrilik, menurunkan kekerasan dan kekasaran permukaan basis gigitiruan [22].

\section{Kesimpulan}

Berdasarkan hasil penelitian yang telah dilakukan, dapat disimpulkan bahwa larutan tablet pembersih gigi-tiruan effervescent memiliki efektivitas yang lebih baik dibandingkan dengan perasan daun kemangi konsentrasi $25 \%, 50 \%, 75 \%$ dan $100 \%$ sebagai pembersih gigi-tiruan resin akrilik yang telah dikontaminasi C. albicans.

\section{Daftar Pustaka}

[1] Phinney, D. J. dan J.H. Halstead. 2002. Delmar's Handbook of Essential Skills and Procedures for Chairside Dental Assisting. Albany: Delmar Publishers.

[2] Noort, R. V. 2013. Introduction to Dental Materials. Fourth Edition. London: Elsevier.

[3] Anusavice, K. J. 2003. Phillips' Science of Dental Materials. Tenth Edition. Florida: Elsevier. Terjemahan oleh A. Budiman. dan S. Purwoko. 2004. Buku Ajar Ilmu Bahan Kedokteran Gigi. Edisi Kesepuluh. Jakarta: EGC.

[4] Paskalis, S. dan A. Irmagita. 2012. Candidal leukoplakia on patient with removable denture. Journal of Dentistry Indonesia. 19(2): 47-50.

[5] Lee, H., C. Li, H. Chang, Y. Yang, dan J. Wu. 2011. Effects of different denture cleaning methods to remove Candida albicans from acrylic resin denture based material. Journal of Dental Sciences. 6: 216220.

[6] Suni, N. A., V. N. S. Wowor. dan M. A. Leman. 2017. Uji daya hambat rebusan daun pepaya (Carica papaya) terhadap pertumbuhan Candida albicans pada plat resin akrilik polimerisasi panas. Jurnal e-Gigi (eG). 5(1).

[7] Himma, F. dan B. S. Purwoko. 2013. Pengaruh jarak tanam terhadap produksi tiga sayuran indigenous. Jurnal Hortikultura Indonesia. 4(1): 26-33.

[8] Hidayat, A. N., M. I. Ilmiawan, dan W. Raharjo. 2014. Uji Aktivitas Antibakteri Fraksi Etanol Daun Kemangi (Ocimum basilicum L.) Terhadap Pertumbuhan Shigella flexneri Secara In Vitro. Naskah Publikasi. Kalimantan Barat: Fakultas Kedokteran Universitas Tanjungpura Pontianak.

[9] Pambudi, R. R., R. Sulistyorini, dan L. O. Mayasari. 2017. Perbedaan Perendaman Plat Resin Akrilik Pada Tablet Pembersih Gigi Tiruan Effervescent dan Air Rebusan Daun Sirih Terhadap Penurunan Jumlah Koloni Jamur Candida albicans. Prosiding Seminar Nasional Publikasi Hasil-Hasil Penelitian dan Pengabdian Masyarakat. Semarang: Fakultas Kedokteran Gigi Universitas Muhammadiyah Semarang.

[10] Stanier, R. Y., J. L. Ingraham, M. L. Wheelis, dan P. R. Painter. 1987. General Microbiology. Fifth Edition. London: Macmillan Press.

[11] Ornay, A. K. D., H. Prehananto, dan A. S. S. Dewi. 2017. Daya hambat pertumbuhan Candida albicans dan daya bunuh Candida albicans ekstrak daun kemangi (Ocimum sanctum I.). Jurnal Wiyata. 4(1).

[12] Soleman, D. dan N. C. E. Setiawan. 2017. Aktivitas antifungi ekstrak metanol kulit batang jambu mete terhadap Candida albicans. Journal Cis-Trans (JC-T). 1(2).

[13]Vifta, R. L., S. K. Khotimah, dan F. P. Luhurningtyas. 2018. Uji aktivitas antifungi ekstrak etanol biji timun suri (Cucumis melo L.) terhadap pertumbuhan Candida albicans secara in vitro. Indonesian Journal of Pharmacy and Natural Product. 1(1): 10-17. 
[14] Mustikasari, K. dan D. Ariyani 2010. Skrining fitokimia ekstrak metanol biji kalangkala (Litsea angulata). Jurnal Sains dan Terapan Kimia. 4(2): 131-136.

[15] Lutfiyanti, R.,W.F. Ma'ruf, dan E. N. Dewi. 2012. Aktivitas antijamur senyawa bioaktif ekstrak Gelidium latifolium terhadap Candida albicans. Jurnal Pengolahan dan Bioteknologi Hasil Perikanan. 1(1): 1-8.

[16] Pulungan, A. S. S. 2017. Aktivitas antijamur ekstrak etanol daun kunyit (Curcuma longa Linn.) terhadap jamur Candida albicans. Jurnal Biologi Lingkungan, Industri, Kesehatan. 3(2): 120-121.

[17] Ningsih, D. R., Zusfahair, dan D. Mantari. 2017. Ekstrak daun mangga (Mangifera indica L.) sebagai antijamur terhadap jamur Candida albicans dan identifikasi golongan senyawanya. Jurnal Kimia Riset. 2(1): 6168.

[18]Djunaedy, A. 2008. Aplikasi fungisida sistemik dan pemanfaatan mikoriza dalam rangka pengendalian patogen tular tanah pada tanaman kedelai (Glycine max L.). Jurnal Embryo. 5(2): 149-157.
[19] Fakhrurrazi., R. F. Hakim, dan C. N. Keumala. 2016. Pengaruh daun asam jawa (Tamarindus Indica Linn) terhadap pertumbuhan Candida albicans. Journal of Syiah Kuala Dentistry Society. 1(1): 2934.

[20]Yuliana, S. R. I., M. A. Leman, dan P. S. Anindita. 2015. Uji daya hambat senyawa saponin batang pisang (Musa paradisiaca) terhadap pertumbuhan Candida albicans. Jurnal e-Gigi (eG). 3(2): 616-620.

[21]Foat, F., Y. W. Cavalcanti, M. M. Bertolini, D. R. Pinto.W. J. Silva, dan A. A. D. B. Cury. 2014. Efficacy of citric acid denture cleanser on the Candida albicans biofilm formed on poly (methyl methacrylate): effects on residual biofilm and recolonization process. Journal Biomed Central Oral Health. 14(77): 1-7.

[22] Utami., S. 2015. Pengaruh Penggunaan Denture Cleanser Terhadap Pertumbuhan Candida albicans Pada Basis Gigi Tiruan Resin Akrilik. Skripsi. Makasar: Fakultas Kedokteran Gigi Universitas Hasanuddin. 